\section{Antiproliferative activities of Artemisia herba-alba ethanolic extract in human colon cancer cell line (HCT116)}

\author{
Giulio Lupidi,1 Massimo Bramucci,1 \\ Luana Quassinti, ${ }^{1}$ Enzo Fornari, ${ }^{1}$ \\ Luca Avenali,1 Hala Khalife, 2 \\ Hala Gali-Muhtasib2 \\ 1School of Pharmacy, Drugs and Health \\ Products, University of Camerino, \\ Camerino, Italy; 2Department of Biology, \\ American University of Beirut, Beirut, \\ Lebanon
}

\section{Abstract}

Artemisia herba-alba (AHE) is a plant commonly used in traditional medicine for the treatment of various ailments. Here, we investigated the antioxidant and antitumor activity of the aqueous and ethanol extracts of AHE in human colon cancer HCT116 cells. The antioxidant activity was measured by DCFH assay, while antitumor effects were assessed by cell viability assays, cell cycle progression by flow cytometry, and DNA fragmentation analysis in addition to investigating the expression of key cell cycle and apoptotic proteins. While the aqueous extract had no antineoplastic effects, the ethanol extract significantly decreased HCT116 viability ( $\mathrm{IC}_{50}$ of $51 \mu \mathrm{g} / \mathrm{mL}$ at $24 \mathrm{~h}$ ) and inhibited the production of reactive oxygen species (ROS). Treatment of HCT116 cells with the ethanol extract also caused dramatic increase in the PreG $_{1}$ population with concomitant decrease in cycling cells, provoked DNA fragmentation, significant increase in the expression levels of p53 and Bax proteins and activated pro-apoptotic caspase-3. The results obtained suggest that the ethanol extract of AHE could be used as an easily accessible source of natural antioxidants and as potential phytochemicals against colon cancer.

\section{Introduction}

Artemisia herba-alba Asso. (syn: A. inculta Del.) (AHE), commonly known as the desert wormwood (Arabic name: Sheeh), is a prominent perennial plant of the Irano-Turanian steppes of Spain, North Africa and the Middle East.1,2 It is mainly used as an aromatisant for tea and in folk medicine for the treatment of colds, coughs, intestinal disturbances, as an antidiabetic agent.3,4 The antileishmania activity of AHE water extract was investigated in vitro against Leishmania tropica and
Leishmania major demonstrating interesting effects. 5 Other common uses of the plant extract include antihelminthic, antimicotic, antispasmodic or vasorelaxant effects.5-7 This species is also recommended for neurological disorders as the ethanolic extract of AHE has shown activity in the GABAA-benzodiazepine receptor assay. ${ }^{8}$ The beneficial effects of the plant are thought to be due to its high antioxidant content, which are even greater than those of green and black tea. ${ }^{9}$ Monoterpene hydrocarbons and oxygenated monoterpenes, such as camphor, 1.8-cineole, p-cymene and davanone, are the most abundant components in AHE essential oil, 10 and the presence of flavonoids and eudesmanolides as isolated classes of constituents in AHE essential oil is reported. ${ }^{11,12}$

Naturally occurring polyphenolic antioxidants have been recognized as one of the most effective classes of colon cancer-preventive agents, since they reduce oxidative stress, a known contributor to carcinogenesis, with little or no systemic toxicity. 13 The lack of detailed mechanistic data about these natural compounds has impeded bringing them to the main stream of medicines for colon cancer prevention or therapy. There is an urgent need for developing novel targeted therapies considering that current therapeutic modalities for colon cancer are associated with toxicity and side effects. ${ }^{14-16}$

In the present study, we investigated the antitumor activity of Artemisia herba-alba in HCT116 human colon cancer cells and determined its potential to cause cell cycle changes, DNA ladder formation and modulate p53, p21 and bax proteins. HCT116 is an aggressive, microsatellite unstable and growth-hormone independent colon cancer cell line which provides an excellent model system not only for basic studies, but also for evaluation of clinical treatment and management of human colon carcinoma. The ethanol extract was found to induce cell death as evidenced by the significant reduction in cell viability, enhanced DNA fragmentation, and increase in the PreG $_{1}$ population in addition to the activation of proapoptotic caspase-3

\section{Materials and Methods}

\section{Preparation of ethanolic and water extracts of Artemisa herba-alba}

Artemisia herba-alba Asso was selected and collected from Dabbous store in Beirut, Lebanon. The plants were already dried when bought and had to be recommended by at least two herbalists. Voucher samples are stored at the Department of MCA of the University of Camerino, Italy (accession numbers CAME No.
Correspondence: Hala Gali-Muhtasib, Department of Biology, American University of Beirut, Lebanon.

Tel. +961.1.350000 - Fax: +961.1.744461

E-mail: amro@aub.edu.lb

Key words: asteraceae; anticancer, cell cycle arrest; herbal drugs, phytotherapy.

Received for publication: 1 September 2011.

Revision received: 4 October 2011.

Accepted for publication: 21 October 2011.

This work is licensed under a Creative Commons Attribution NonCommercial 3.0 License (CC BYNC 3.0).

(C) Copyright G. Lupidi et al., 2011

Licensee PAGEPress, Italy

Alternative Medicine Studies 2011; 1:e14

doi:10.4081/ams.2011.e14

0010). The dried plant material was grounded and stored in brown glass bottles until use. For preparing the ethanol or water extracts, 5 grams of the powder was dissolved either in 50 $\mathrm{mL}$ of absolute ethanol or in $50 \mathrm{~mL}$ of distilled water, respectively. Afterwards, the mixture was homogenised by Ultra-Turrax disperser and centrifuged at $12,000 \times g$ for $10 \mathrm{~min}$ and the extract was filtered. The ethanol was evaporated with the rotor-vapor, obtaining a viscous gel which was stored at $-20^{\circ} \mathrm{C}$ in a dark ampule. The water extract mixture was lyophilised, and the dried mixture was stored at $-20^{\circ} \mathrm{C}$.

\section{Determination of total phenolics}

The amount of total soluble phenolics (TPH) was determined according to the FolinCiocalteu method. ${ }^{17}$ Different samples of water and ethanol extracts were prepared: solutions of $3 \mathrm{mg} / \mathrm{mL}$ of water extract and $1 \mathrm{mg} / \mathrm{mL}$ of ethanol extract. The Folin Reactive was prepared by bringing $3 \mathrm{~mL}$ of Folin-Ciocalteu phenol reagent to a $30 \mathrm{~mL}$ final volume with distilled water; $75 \% \mathrm{Na}_{2} \mathrm{CO}_{3}$ solution was prepared and added in the assay to activate the reaction. The titration curve was obtained using quercetin as a standard control. The absorbance was measured at $765 \mathrm{~nm}$ in a Varian Cary-1 spectrophotometer. The total phenolic content was determined as quercetin equivalents per mg of extract.

\section{Measurement of intracellular ROS generation}

The production of intracellular reactive oxygen species (ROS) was measured using the oxidation-sensitive fluorescent dye 2,7dichlorodihydrofluorescin diacetate (DCDHF) according to published protocols.18 Briefly, cells were harvested and washed in HBSS/HEPES supplemented with $0.2 \%$ BSA 
and loaded for $60 \mathrm{~min}$. at $37^{\circ} \mathrm{C}, 5 \% \mathrm{CO}_{2}$ with $10 \mu \mathrm{g} / \mathrm{mL}$ of DCDHF. For fluorescence measurements, cells were harvested by trypsinisation and resuspended in $1 \mathrm{~mL}$ of HBSS/HEPES supplemented with $1 \%$ fetal bovine serum (FBS), to prevent dye leakage, transferred to a quartz cuvette, incubated at $37^{\circ} \mathrm{C}$ and maintained under continuous stirring. Artemisia extract was then added (25, 50 and $100 \mu \mathrm{g} / \mathrm{mL})$ and the fluorescence intensity was monitored for 30 min by spectrofluorimetry. The excitation wavelength was set at $488 \mathrm{~nm}$ and the emission wavelength was $543 \mathrm{~nm}$. The effect of the extract was also evaluated in the presence of $200 \mu \mathrm{M}$ tert-butyl hydroperoxide (t-BHP).

\section{Cell proliferation}

Human colon cancer HCT116 (+/+ p53) cells were kindly provided by Dr. Carlos Galmarini (Institut National de la Sante et de la Recherche Medicale, Lyon, France). Cells were cultured in RPMI 1640 supplemented with $2 \mathrm{mM}$ L-glutamine, 100 units/mL penicillin, $100 \mu \mathrm{g} / \mathrm{mL}$ streptomycin, and $10 \%$ heatinactivated FBS (all obtained from Sigma, St. Louis, M0, USA). The cells were grown in a humidified atmosphere of $5 \% \mathrm{CO}_{2}$ in air at $37^{\circ} \mathrm{C}$. The viability of HCT116 cells was determined by the standard 3-(4,5-Dimethylthiazol2-yl)-2,5-diphenyltetrazolium bromide (MTT) assay. The cells were seeded in 96 -well plates in $100 \mu \mathrm{L}$ of growth medium $\left(5 \times 10^{3}\right.$ cells/well). After $24 \mathrm{~h}$, cells were exposed to different concentrations of AHE extracts (3.125 to 200 $\mu \mathrm{g} / \mathrm{mL}$ ) containing $0.5 \%$ of ethanol which was applied as control (vc) and incubated for $24 \mathrm{~h}$ or $48 \mathrm{~h}$. Cell viability was quantified by the ability of living cells to reduce the yellow dye thiazolyl blue tetrazolium bromide (MTT) to a purple formazan product. At the end of incubation, $10 \mu \mathrm{L}$ MTT $(5 \mathrm{mg} / \mathrm{mL}$ in phosphatebuffered saline, PBS) per well was added and incubated for $4 \mathrm{~h}$ at $37^{\circ} \mathrm{C}$. The formazan product was then dissolved in $100 \mu \mathrm{L}$ dimethyl sulphoxide (DMSO) after aspirating the medium and the absorbance was measured at 540 $\mathrm{nm}$ using a Titertek Multiscan MicroElisa (Labsystems, Helsinki, Finland). Cell viability was calculated as the percentage ratio of the sample absorbance to the reference control. $\mathrm{IC}_{50}$ represents the extract concentration showing a lethal effect on $50 \%$ of the cells.

\section{Flow cytometric analysis of DNA content}

Flow cytometric analysis of DNA content was determined according to published protocols. ${ }^{19}$ HCT116 human colon cancer cells were seeded in $100 \mathrm{~mm}$ dishes at $1.2 \times 10^{5}$ cells per well. They were then incubated and allowed to grow to $50 \%$ confluence after which they were treated with AHE extract $(1.45 \mu \mathrm{g} / \mathrm{mL}$ of polyphenols and $2.50 \mu \mathrm{g} / \mathrm{mL}$ of polyphenols) for $24 \mathrm{~h}$ or $48 \mathrm{~h}$.
They were then harvested by trypsin release and washed twice with PBS. The pellet was resuspended in an ice-cold solution of $70 \%$ ethanol in PBS (v/v). After $2 \mathrm{~h}$ of fixation, cells were washed twice with PBS. Fixed cells were stained by suspension in a solution of propidium iodide (100 $\mu \mathrm{g} / \mathrm{mL}$ final concentration; Molecular probes, Eugene, OR) and 1\% RNase A (Sigma Chemical Co, St. Louis, M0). Distribution of cell cycle phases with different DNA contents was determined using a FACScan flow cytometer (Becton- Dickinson, San Jose, $\mathrm{CA})$. Cells that were less intensely stained than $\mathrm{G}_{1}$ cells (sub $\mathrm{G}_{1}$ cells) in flow cytometric histograms were considered apoptotic. Analysis of cell cycle distribution and the percentage of cells in the $G_{1}, S$ and $G_{2} / M$ phases of the cell cycle were determined using Cell Quest.

\section{DNA gel electrophoresis}

Conventional agarose gel electrophoresis was done as described previously with some modifications. ${ }^{20}$ Briefly, HCT116 $\left(3 \times 10^{6}\right.$ cells $)$ were exposed to AHE ethanolic extract at a final concentration of $50 \mu \mathrm{g} / \mathrm{mL}$. After $24 \mathrm{~h}$ of incubation, cells were washed with PBS, trypsinised, and centrifuged at $500 \times g$ for 5 min. The pellet was suspended in $400 \mu \mathrm{L}$ of icecold lysis buffer (20 mM Tris-HCl, pH 8.0, 10 mM EDTA, $0.2 \%$ Triton X-100) for $15 \mathrm{~min}$. The samples were then centrifuged at $12,000 \times g$ for 15 min. The supernatant was collected, proteinase $\mathrm{K}(1 \mathrm{mg} / \mathrm{mL})$ was added, and then incubated for $2 \mathrm{~h}$ at $56^{\circ} \mathrm{C}$. RNase was added to the supernatant to a final concentration of 0.5 $\mathrm{mg} / \mathrm{mL}$, and the resulting suspension was incubated for $2 \mathrm{~h}$ at $56^{\circ} \mathrm{C}$. To each tube, $0.5 \mathrm{~mL}$ of phenol:chloroform:isoamyl alcohol (25:24:1) was added, mixed and centrifuged at 12,000 $\times g$ for 2 min to separate the DNA containing upper aqueous phase. To the resulting aqueous phase, two volumes of ice-cold absolute ethanol and $1 / 10^{\text {th }}$ volume of $5 \mathrm{M}$ sodium acetate were added and incubated overnight at $-20^{\circ} \mathrm{C}$ to precipitate DNA. DNA was pelleted by centrifuging at $12,000 \times g$ for $10 \mathrm{~min}$ at $40^{\circ} \mathrm{C}$; the supernatant was aspirated and the pellet was washed with $1 \mathrm{~mL}$ of $70 \%$ ethanol. After repeating the above centrifugation step and removing the last traces of the supernatant fraction, the pellet was allowed to dry at room temperature and resuspended in $10 \mu \mathrm{L}$ of TBE buffer $(90 \mathrm{mM}$ Tris, $90 \mathrm{mM}$ borate, and $10 \mathrm{mM}$ EDTA, $\mathrm{pH}$ 8.0) and $2.5 \mu \mathrm{L}$ of sample buffer (30\% glycerol, $0.25 \%$ bromophenol blue). DNA samples were resolved on $1 \%$ agarose gel containing 0.1 $\mu \mathrm{g} / \mathrm{mL}$ ethidium bromide using TBE as the running buffer for $150 \mathrm{~min}$ at $40 \mathrm{~V}$. The gel was then visualised under a UV transilluminator.

\section{Caspase-3 activity}

Activation of caspase- 3 was measured by using colorimetric Caspase-3 Assay Kit (Sigma, St. Louis, M0, USA). Cells incubated

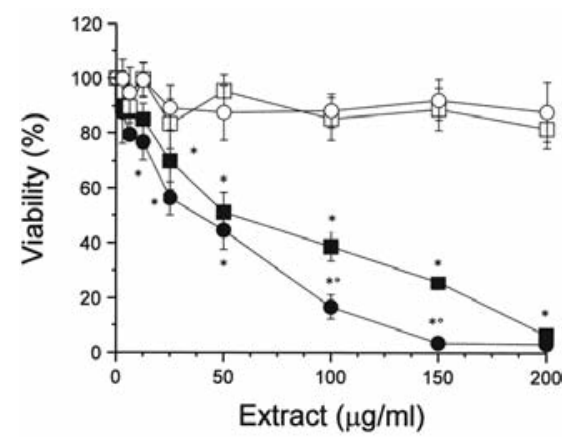

Figure 1. Artemisia herba-alba ethanolic extract reduces the viability of HCT116 cells. Cells were grown in microtiter plates and exposed to ethanolic or water extract $(3.125$ to $200 \mu \mathrm{g} / \mathrm{mL}$ ). Cell viability was assessed after $24 \mathrm{~h}(\square, \square)$ and $48 \mathrm{~h}(0, \bigcirc)$ for ethanolic $(\square, 0)$ and water $(\square, \bigcirc)$ extracts by MTT assay. Comparisons between treated and control cells were evaluated using t-test. The level of significance was set at $0.05\left({ }^{*} \mathrm{P}<0.05\right.$ vs control, ${ }^{\circ} \mathrm{P}<0.05$ vs $24 \mathrm{~h}$ ).
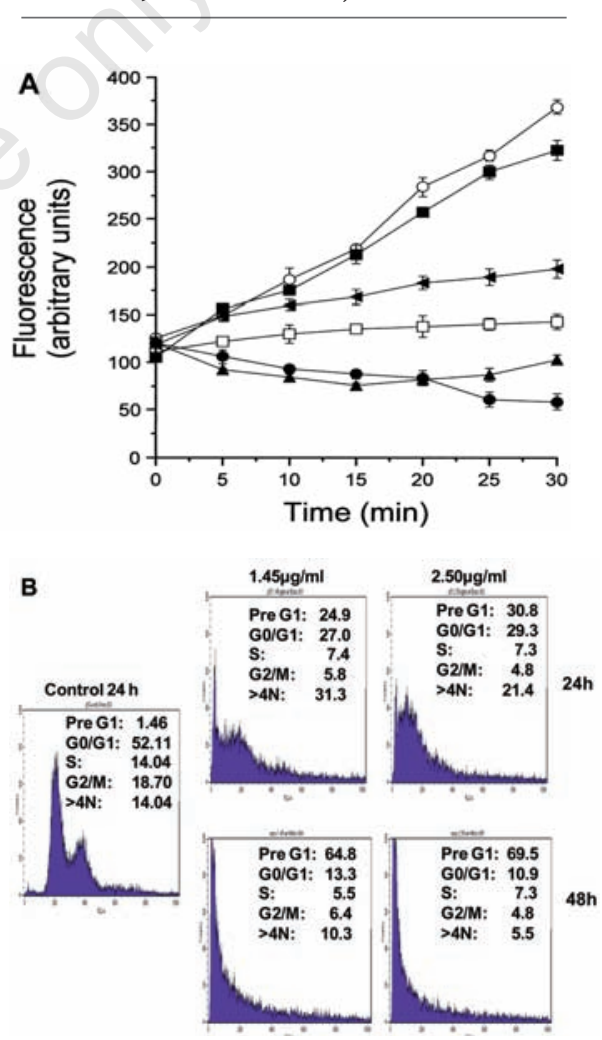

Figure 2. Artemisia herba-alba ethanolic extract increases the PreG1 population and enhances the generation of reactive oxygen species. (A) Cells, loaded with the fluorescent dye DCDHF, were treated with 100 $\mu \mathrm{g} / \mathrm{mL}$ (p) of ethanolic extract or with vehicle $(\square)$. The scavenger activity of the ethanolic extract at $25 \mu \mathrm{g} / \mathrm{mL}$ ( $\square$ ), 50 $\mu \mathrm{g} / \mathrm{mL}(\mathrm{t})$, and $100 \mu \mathrm{g} / \mathrm{mL}(0)$ was also evaluated in the presence of $200 \mu \mathrm{M}$ tertbutyl hydroperoxide (t-BHP) (○). (B) Cells were treated with $1.45 \mu \mathrm{g} / \mathrm{mL}$ or $2.5 \mu \mathrm{g} / \mathrm{mL}$ of ethanol extract for $24 \mathrm{~h}$ and $48 \mathrm{~h}$ and cell cycle profiles were analyzed by flow cytometry after DNA staining with propidium iodide. In A-C, values represent the mean ( \pm SD) of three independent experiments. 
with 50 or $100 \mu \mathrm{g} / \mathrm{mL}$ of AHE extract for different times (1, 2, 4, 12 and 24 h.) were harvested, washed with PBS and the pellets were resuspended in lysis buffer $(50 \mu \mathrm{L})$ for $20 \mathrm{~min}$. Lysates were centrifuged at $20,000 \times g$ for 10 min at $40^{\circ} \mathrm{C}$, and supernatants were collected and added to 96-well plates. Final reaction buffer $(100 \mu \mathrm{L})$ and caspase-3 colorimetric substrate (Ac-DEVDpNA $10 \mu \mathrm{L}$ ) were then added to each well. Plates were incubated at $37^{\circ} \mathrm{C}$ for $2 \mathrm{~h}$ and optical density was measured at $405 \mathrm{~nm}$ with a Titertek Multiscan MicroElisa (Labsystems, Helsinki).

\section{Western blot analysis}

HCT116 human colon cancer cells were treated at $50 \%$ confluence with the AHE ethanol extract for $24 \mathrm{~h}$. At the end of the incubation period, $30 \mathrm{mg}$ of cytoplasmic protein extracts were prepared and resolved on $12 \%$ polyacrylamide gels and transferred to a nitrocellulose membrane. The blot was blocked in blocking buffer ( $1 \%$ non fat dry milk/1\% Tween 20 in PBS) for $1 \mathrm{~h}$ at room temperature, and then incubated with appropriate monoclonal primary antibodies (human reactive p53 from Santa Cruz Biotechnology, p21 from Biosource, and Bax from BD Biosciences). The blot was then incubated with appropriate secondary horseradish peroxidase-conjugated antibody and detected by chemiluminescence and autoradiography using X-ray film. GADPH was used as loading control.

\section{Statistical analysis}

Results are expressed as means \pm standard deviation (SD). Statistical analysis was performed using SPSS Student Version 11.0 Software Package. Comparisons between different treatments were evaluated using a onetailed Student's t-test. The level of significance was set at 0.05 .

\section{Results}

Since ancient times, plants have been used to treat various diseases, and their uses have been reported in the ancient literature of indigenous systems of medicine. ${ }^{21}$ The search for new anti-cancer drugs is one of the most prominent areas of natural products research, and in recent years there is considerable interest in identifying novel botanicals that selectively induce growth arrest of cancer cells without affecting normal cells. Several natural compounds have been found to exhibit chemopreventive activities both in vitro and in vivo. These compounds are able to induce apoptosis in a number of experimental models of carcinogenesis, 21,22 and to prevent the development of colon cancer both in vitro and in vivo.23-27
Artemisia herba-alba Asso is a plant that is used extensively in folk medicine in the Mediterranean region.1,2,28-33 Despite reported biological, pharmacological, and toxicological activities of Artemisia herba-alba, there has been no published work on the effects of extracts or components of this plant on cancer cells. In this study we investigated, for the first time, the antioxidant and anti-colon-cancer activities of AHE Asso. The effects of aqueous and ethanolic extracts of AHE on HCT116 human colon cancer cell viability was determined using MTT assay. Cells were exposed to various concentrations of AHE extracts for $24 \mathrm{~h}$ and $48 \mathrm{~h}$, and only the ethanolic extract significantly $(\mathrm{P}<0.05)$ reduced the viability of HCT116 cells in a dose- and time-dependent manner (Figure 1). The inhibitory activity was $83 \%$ after $48 \mathrm{~h}$ in the presence of $100 \mu \mathrm{g} / \mathrm{mL}$ of ethanol extract. The $\mathrm{IC}_{50}$ values were 50.92 $\mu \mathrm{g} / \mathrm{mL}$ (44.53-58.23 $\mu \mathrm{g} / \mathrm{mL}, 95 \%$ confidence interval) and $32.73 \mu \mathrm{g} / \mathrm{mL}(27.73-38.65 \mu \mathrm{g} / \mathrm{mL}$, $95 \%$ confidence interval) for $24 \mathrm{~h}$ and $48 \mathrm{~h}$ of incubation, respectively. The aqueous extract

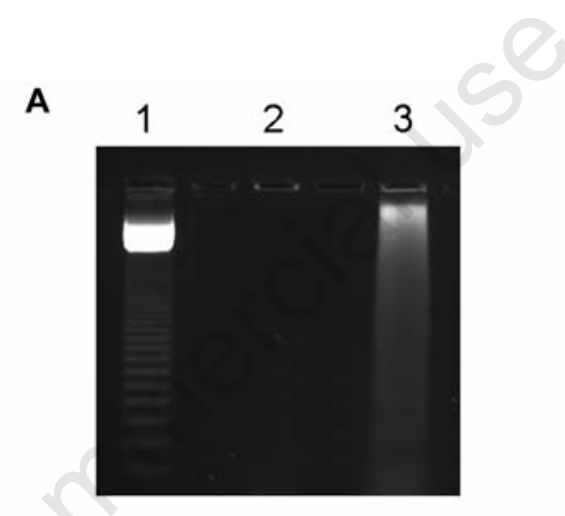

B
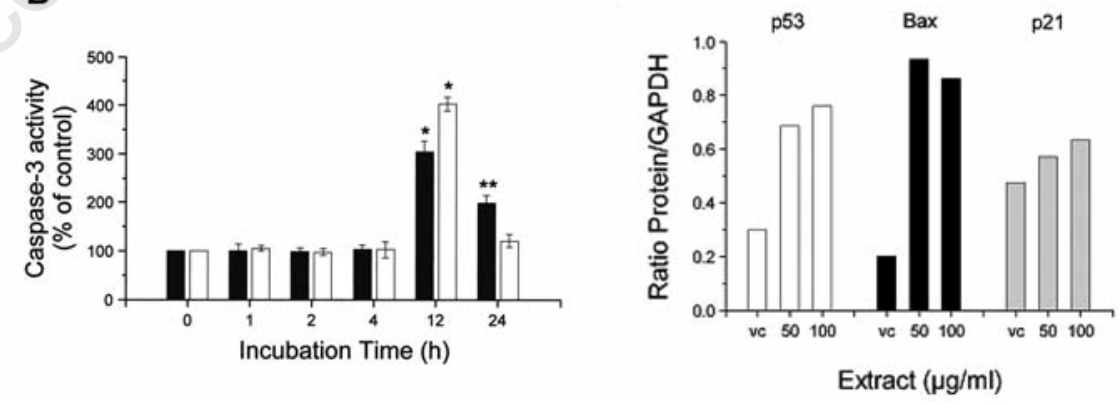

showed no effect on colon cancer cell viability (Figure 1), therefore, all later experiments were done with the ethanol extract.

Since the generation of reactive oxygen species (ROS) is an important mode of action of many anticancer agents, we explored whether cell death induced by AHE extract is due to its pro-oxidant effects. ROS generation was measured using the fluorescent dye DCF. Cell treatment with ethanolic extract (100 $\mu \mathrm{g} / \mathrm{mL}$ ) decreased the fluorescent signal progressively to almost $50 \%$ of the control value after 15 min of incubation, suggesting a strong antioxidant activity (Figure 2A). Protection against exogenous oxidative stress was further evidenced by incubating cells in the presence of $200 \mu \mathrm{M}$ t-BHP. The inhibition of ROS production was dose-dependent increasing with the amount of the ethanol extract.

To further determine and confirm whether or not the observed reduction in cell viability by the AHE extract was related to induction of apoptosis, the subdiploid fraction (characteristic of apoptosis) was measured by PI staining

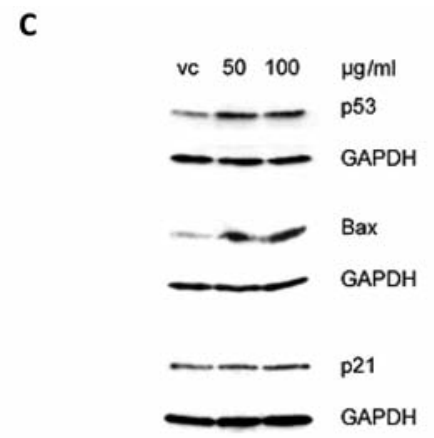

D

Figure 3. Artemisia herba-alba ethanolic extract causes DNA fragmentation, activates caspase- 3 and increases $\mathrm{p} 53$ and Bax proteins. A) HCT116 cells were incubated with vehicle (lane 2) or with $50 \mu \mathrm{g} / \mathrm{mL}$ of AHE ethanolic extract for $24 \mathrm{~h}$ (lane 3) and genomic DNA prepared as described in Materials and Methods. Lane 1 represents 123-bp DNA size marker. A representative of three independent experiments is shown; B) Caspase-3 activation was determined in the cytosolic fraction of HCT116 cells using colorimetric assay, after treatment with 50 (口) or 100 (घ) $\mu \mathrm{g} / \mathrm{mL}$ of AHE for 1, 2, 4, 12 and $24 \mathrm{~h}$. Data represent the mean $( \pm$ S.E. $)$ from three independent experiments versus control. $\left(^{* *}\right)$ $\mathrm{P}<0.001,\left(^{*}\right) \mathrm{P}<0.05$, vs control; C) For western blotting, cells were treated with vehicle $(\mathrm{vc})$ or with the indicated concentrations of ethanolic extract for $24 \mathrm{~h}$ and whole cell lysates were prepared. Blots were incubated with mouse anti-p53, anti-Bax, and anti-p21 antibodies and then incubated with anti-mouse secondary horseradish peroxidase-conjugated antibody. Bands were detected by luminescence and autoradiography. GAPDH was included as a loading control; D) Bands were quantified using image capture and analysis system (Kodak MI, Rochester, NY, USA). 
of DNA content with flow cytometry. We investigated the mode of action of the extract on cellular parameters, including cell cycle distribution and apoptosis induction using extract concentrations that range below and above the $\mathrm{IC}_{50}$. Treatment with $1.45 \mu \mathrm{g} / \mathrm{mL}$ and 2.50 $\mu \mathrm{g} / \mathrm{mL}$ of the AHE ethanol extract for $24 \mathrm{~h}$ or 48 $h$ caused dramatic increases in the pre- $\mathrm{G}_{1}$ population (a hallmark of apoptosis and necrosis) with respect to control cells in addition to a significant decrease in the proportion of cells in $\mathrm{G}_{0} / \mathrm{G}_{1}, \mathrm{~S}$ and $\mathrm{G}_{2} / \mathrm{M}$ phases (Figure $2 \mathrm{~B}$ ).

To investigate whether AHE triggers DNA fragmentation, genomic DNA was isolated from cells incubated for $24 \mathrm{~h}$ with $50 \mu \mathrm{g} / \mathrm{mL}$ of ethanolic extract and analyzed on $1 \%$ agarosegel electrophoresis. Figure 3A shows the presence of typical DNA laddering, suggesting the activation of apoptotic processes by the ethanol extract. To elucidate the apoptogenic effects of AHE, we evaluated the extract effects on caspase-3. Caspase-3 is a well-known executor enzyme in the apoptotic pathway. Treatment of HCT116 cells with $\mathrm{IC}_{50}$ concentrations of the ethanol extract markedly enhanced caspase- 3 activity with respect to the control (Figure 3B). Caspase-3 significantly increased in the cells after $12 \mathrm{~h}$ of incubation with AHE, and no higher expression levels of caspase-3 were observed at $24 \mathrm{~h}$. Since caspase activation was observed, the effects of the AHE extract on the regulation of apoptosis-related genes such as Bax, p53, and p21 were investigated. We conducted Western blot analyses to determine the levels of Bax, p53 and p21 proteins and as expected, the levels of Bax protein in cells incubated with AHE ethanolic extract increased significantly (Figure 3C). Bax levels increased by 4.6 and 4.3 fold with respect to control after $24 \mathrm{~h}$ of incubation with 50 and 100 $\mu \mathrm{g} / \mathrm{mL}$ of ethanol extract, respectively (Figure 3D). Similarly, the expression of p53 protein was increased (2.3 and 2.5 fold with respect to control) and moderate increase in p21 protein expression was observed in response to treatment with the ethanol extract. The pro-apoptotic protein Bax can indirectly activate caspase-3 through activation of caspase-9. The increase in Bax expression, an index of apoptotic cell death, suggests the involvement of the mitochondrial pathway in AHE-induced apoptosis.

In conclusion, this study shows that exposure of HCT116 human colon cancer cells to Artemisia herba-alba ethanol extract decreases cell viability, causes DNA damage, and induces apoptosis via the activation of caspase- 3 and increase in Bax and p53 proteins. Further biochemical and molecular studies of the ethanol extract should be carried out in different types of cancer cell lines and in animal models of colon cancer to establish its therapeutic efficacy. As reported, sesquiterpene lactones, which are among the prominent natural products found in Artemisia species, could be the promising candidates for the observed effects. 34 Further investigations to identify and characterize the efficacious phytotherapeutic bioactive compounds of Artemisia herba-alba are currently in progress, however, our data support the role of AHE ethanol extract against colon cancer.

\section{References}

1. Al-Qura'n S. Ethnopharmacological survey of wild medicinal plants in Showbak, Jordan J Ethnopharmacol 2009;123:45-50.

2. Saleh MA, Belal MH, el-Baroty G. Fungicidal activity of Artemisia herba-alba Asso (Asteraceae). J Environ Sci Health B 2006;41:237-44.

3. Al-Shamaony L, Al-Khazraji SM, Twaij HA. Hypoglycemic effect of Artemisia herbaalba.II. Effect of a valuable extract on some blood parameters in diabetic animals. J Ethnopharmacol 1994;43:167-71.

4. Boriky D, Berrada M, Talbi M, Keravis GF. Eudesmanolides from Artemisia herbaalba. Phytochemistry 1996;3:309-11.

5. Hatimi S, Boudouma M, Bichichi M et al. In vitro evaluation of antileishmania activity of Artemisia herba-alba Asso. Bull Soc Pathol Exot 2001;94:29-31.

6. Yashphe J, Segal R, Breuer A, ErdreichNaftali G. Antibacterial activity of Artemisia herba-alba. J Pharm Sci 1979;68: 924-5.

7. Skiker M, Mekhfi H, Aziz M et al. Artemisia herba-alba Asso relaxes the rat aorta through activation of NO/cGMP pathway and K(ATP) channels. J Smooth Muscle Res 2010;46:165-74.

8. Salah SM, Jager AK. Two flavonoids from Artemisia herba-alba Asso with in vitro $\mathrm{GAB}_{\mathrm{AA}}$-benzodiazepine receptor activity. $\mathrm{J}$ Ethnopharmacol 2005;99:145-6.

9. Abid ZB, Feki M, Hedhili A, Hamdaoui MH. Artemisia herba-alba Asso (Asteraceae) has equivalent effects to green and black tea decoctions on antioxidant processes and some metabolic parameters in rats. Ann Nutr Meta 2007;51:216-22.

10. Abou El-Hamd M, El-Sayed M, Hegazy M et al. Chemical constituents and biological activities of Artemisia herba-alba. Rec Nat Prod 2010;4:1-25.

11. Haouari M, Ferchichi A. Essential oil composition of Artemisia herba-alba from Southern Tunisia Molecules 2009;14:1585-94.

12. Hudaib M, Aburjai T. Composition of the essential oil from Artemisia herba-alba grown in Jordan. J Essen Oil Res 2006;18:301-4.

13. Tseng TH, Lee YJ. Evaluation of natural and synthetic compounds from East
Asiatic folk medicinal plants on the mediation of cancer. Anticancer Agents Med Chem 2006;6:347-65.

14. Baer-Dubowska W. Cancer chemopreventive agents-drugs for the $21^{\text {st }}$ century? Acta Pol Pharm 2006;63:369-73.

15. Boursi B, Arber N. Current and future clinical strategies in colon cancer prevention and the emerging role of chemoprevention. Curr Pharm Des 2007;13:2274-82.

16 Imai $\mathrm{M}$, Kikuchi $\mathrm{H}$, Denda $\mathrm{T}$ et al. Cytotoxic effects of flavonoids against a human colon cancer derived cell line, COLO 201: a potential natural anti-cancer substance. Cancer Lett 2009;276:74-80.

17. Katsube T, Tabata H, Ohta Y et al. Screening for antioxidant activity in edible plant products: comparison of LowDensity Lipoprotein 0xidation Assay, DPPH, radical scavenging assay and Folinciocalteu assay. J Agric Food Chem 2004;58:2391-6.

18. Le Bel C, Ischiropoulos H, Bondy SC. Evaluation of the probe 2,7-dichlorofluorescin as an indicator of reactive oxygen species formation and oxidative stress. Chem Res Toxicol 1992;5:227-31.

19. Riccardi R, Nicoletti I. Analysis of apoptosis by propidium iodide staining and flow cytometry. Nature Protocols 2006;1:1458-61.

20. Herrmann M, Lorenz HM, Voll R et al. A rapid and simple method for the isolation of apoptotic DNA fragments. Nuc Acid Res 1994;22:5506-7.

21. Surh YJ. Cancer chemoprevention with dietary phytochemicals. Nat Rev Cancer 2003;3:768-80.

22. Coseri S. Natural products and their analogues as efficient anticancer drugs. Mini Rev Med Chem 2009;9:560-71.

23. Kyle JA, Sharp L, Little J et al. Dietary flavonoid intake and colorectal cancer: a casecontrol study. Br J Nutr 2010;103:429-36.

24. Link A, Balaguer F, Goel A. Cancer chemoprevention by dietary polyphenols: Promising role for epigenetics. Biochem Pharmacol 2010;80:1771-92.

25. Landis-Piwowar KR, Milacic V, Dou QP. Relationship between the methylation status of dietary flavonoids and their growthinhibitory and apoptosis-inducing activities in human cancer cells. J Cell Biochem 2008;105:514-23.

26. Braun L, Cohen M. Herbs and Natural Supplements: An Evidence-based Guide, $2^{\text {nd }}$ ed. Elsevier, Harcourt Australia; 2007.

27. Blijham GH. Chemotherapy of colorectal cancer. Anticancer Drugs 1991;2:233-45.

28. Bailey C, Danin A. Bedouin plant utilization in Sinai and Negev. Econ Bot 1981;35:145-62.

29. Jouad H, Haloui M, Rhiouani $H$ et al. Ethnobotanical survey of medicinal plants used for the treatment of diabetes, cardiac 
and renal diseases in the North centre region of Morocco (Fez-Boulemane). J Ethnopharmacol 2001;77:175-82.

30. Segal R, Feuerstein I, Danin A. Chemotypes of Artemisia herba-alba in Israel based on their sesquiterpene lactone and essential oil constitution. Phytochemistry 1987;15:411-6.

31. Ziyyat A, Legssyer A, Mekhfi $\mathrm{H}$ et al.
Phytotherapy of hypertension and diabetes in oriental Morocco. J Ethnopharmacol 1997;58:45-54.

32. Tahraoui A, El-Hilaly, Israili ZH, Lyoussi B. Ethnopharmacological survey of plants traditional treatment of hypertension and diabetes in south-eastern Morocco (Errachidia province). J Ethnopharmacol 2007;110:105-17.
33. Zeggwagh N-A, Farid 0, Michel JB et al. Cardiovascular effect of Artemisia herbaalba aqueous extract in spontaneously hypertensive rats. Methods Find Exp Clin Pharmacol 2008;30:375-81.

34. Ghantous A, Gali-Muhtasib H, Vuorela H et al. What made sesquiterpene lactones reach cancer clinical trials? Drug Discov Today 2010;15:668-78. 